\title{
Analisis modal kerja untuk meningkatkan profitabilitas
}

\author{
Yuniar Ambarwati; Hermi Sularsih*; Datuk Maralelo Siregar
}

\author{
Sekolah Tinggi Ilmu Ekonomi Gempol \\ *E-mail korespondensi: hermisularsihstieg@gmail.com
}

\begin{abstract}
The research objective was to determine the working capital management of UD. Nila Kencana and to see the management of working capital in increasing the profitability of UD. Nila Kencana. In this study, the type of research chosen is descriptive research with a quantitative approach or field research, which is a research method that is inductive, objective, and scientific in which the data obtained is in the form of numbers or statements that are scored, and analyzed by analysis. statistics. The results showed that the level of networking capital increased in 2017-2018. Management of current and current assets in an effective way using the right policies will provide results in the form of profits that are planned for working capital management in 2016-2017 which is effective with working capital management balanced with an increase in company profits. Meanwhile, in 2017-2018 the effectiveness of increasing working capital was not matched by an increase in company profits. Meanwhile, in 2017-2018 the effectiveness of increasing working capital was not matched by an increase in company profits. This is due to an increase in the cost of goods manufactured which indicates an increase in the level of purchases in 2018 and has an impact on the cost of goods sold.
\end{abstract}

Keywords: Working capital, Profitability, Financial ratio

\begin{abstract}
Abstrak
Tujuan penelitian ini untuk mengetahui pengelolaan modal kerja UD. Nila Kencana dan untuk mengetahui pengelolaan modal kerja dalam meningkatkan profitabilitas UD. Nila Kencana. Dalam penelitian ini, jenis penelitian yang yang dipilih adalah dengan penelitian deskriptif dengan pendekatan kuantitatif atau fieldresearch yaitu suatu metode penelitian yang bersifat induktif, objektif dan ilmiah dimana data yang di peroleh berupa angka-angka atau pernyataan-pernyataan yang di nilai, dan dianalisis dengan analisis statistik. Hasil penelitian menunjukan tingkat Net working capital yang meningkat pada tahun 2017-2018. Pengelolaan-pengelolaan aktiva lancar dan hutang lancar secara efektif dengan menggunakan kebijakan yang tepat akan memberikan hasil berupa laba yang ditargetkan pengelolaan modal kerja pada tahun 2016-2017 sudah efektif dengan pembuktian meningkatnya modal kerja yang diimbangi peningkatan laba perusahaan. Sedangkan pada tahun 2017-2018 keefektifan peningkatan modal kerja tidak diimbangi dengan peningkatan laba perusahaan. Sedangkan pada tahun 2017-2018 keefektifan peningkatan modal kerja tidak diimbangi dengan peningkatan laba perusahaan. Hal ini disebabkan adanya kenaikan harga bahan pokok produksi yang menunjukkan naiknya tingkat pembelian pada tahun 2018, dan berimbas pada meningkatnya beban pokok penjualan.
\end{abstract}

Kata Kunci: Modal kerja, Profitabilitas, Rasio keuangan 


\section{PENDAHULUAN}

Dalam dunia bisnis, pada umumnya setiap perusahaan mempunyai tujuan untuk memperoleh laba. Dalam mencapai tujuan tersebut, setiap perusahaan dituntut untuk mengoptimalkan dan memanfaatkan potensi yang dimiliki perusahaan dengan baik, terutama berkaitan dengan pengelolaan modal kerja. Hal ini karena, modal kerja merupakan faktor utama penggerak operasional perusahaan, dimana lebih separuh dari jumlah aktiva perusahaan adalah aktiva lancar yang merupakan unsur modal kerja. (Wibowo: 2008), pengelolaan dan penggunaan modal kerja yang efektif merupakan salah satu faktor yang dapat menunjang pencapaian laba secara optimal.

Modal kerja (Riyanto: 2007) dalam perusahaan selalu dalam keadaan berputar selama perusahaan yang bersangkutan beroperasi. Periode perputaran modal kerja dimulai dari saat kas diinvestasikan dalam komponen-komponen modal kerja sampai saat kembali lagi menjadi kas. Semakin pendek periode tersebut berarti semakin cepat perputarannya, sehingga semakin pendek periode perputarannya modal kerja tersebut akan lebih efisien.

Modal kerja (Martono dan Harjito: 2005) yang baik merupakan modal kerja yang dapat menaikkan tingkat nilai dari perusahaan itu sendiri dengan cara memilih sumber dan menggunakan modal kerja itu dengan tepat, sehingga profitabilitas yang diperoleh meningkat. Salah satu cara untuk mencapai keuntungan yang optimal, adalah dengan cara mengalokasikan modal kerja yang tepat dan efisien dalam aktivitas perusahaan. Modal Kerja (Ni Wayan Yulianti: 2013) pendanaan modal kerja berpengaruh tidak signifikan terhadap profitabilitas.

Modal kerja merupakan salah satu komponen penting dalam menjalankan aktivitas usaha perusahaan. Modal kerja (Sugiyarso dan Winarni : 2005) adalah dana yang ditanamkan ke dalam aktiva lancar untuk membiayai operasi perusahaan sehari-hari. Modal kerja yang digunakan diharapkan akan dapat kembali masuk dalam waktu pendek melalui penjualan. Hal ini dikarenakan modal kerja akan berputar secara terus menerus setiap periodenya dapat dialokasikan kembali untuk membiayai operasi perusahaan. Melalui pengelolaan yang baik, diharapkan modal yang tertanam dalam bentuk modal kerja tersebut dapat dimanfaatkan secara efisien dan seefektif mungkin. Manajemen keuangan berperan penting dalam perencanaan dan pengalokasian modal, berhasil atau tidaknya tujuan perusahaan tergantung pada pengelolaan modal yang tersedia. Dalam perencanaan pengalokasian modal, manajemen keuangan dituntut untuk mampu melakukan efesiensi, semua ini dapat diwujudkan dengan menarik suatu keputusan dalam kebijakan menetukan modal yang dibutuhkan. Untuk mengukur kinerja perusahaan dapat dilakukan dengan mengukur kemampuan untuk memperoleh laba/ keuntungan (profitabilitas).

Profitabilitas (Sugiyarso dan Winarni: 2005) adalah kemampuan perusahaan dalam menghasilkan keuntungan (profit), dari definisi ini terlihat jelas bahwa sasaran yang akan dicari adalah laba perusahaan. Dimana profitabilitas ini merupakan hasil akhir bersih dari berbagai kebijakan dan keputusan manajemen. Rasio profitabilitas akan memberikan jawaban akhir tentang efektifitas manajemen perusahaan, rasio ini memberi gambaran tentang efektifitas pengelolaan perusahaan. Rasio profitabilitas ini dijadikan sebagai ukuran untuk menilai kemampuan perusahaan di dalam menghasilkan laba dan rasio ini diharapkan dapat membantu menilai kinerja pada UD. Nila Kencana.

UD Nila Kencana yang beralamat di Jl Raya Sambisirah, Pasuruan, Jawa Timur, memusatkan perhatian untuk memperoleh laba yang maksimal dan berusaha untuk 
mempertahankan kelangsungan hidup perusahaan dengan menggunakan segala kemampuan serta sumber daya yang tersedia yang pada akhirnya dapat meningkatkan kesejahteraan anggota/karyawan UD Nila Kencana. Di UD Nila Kencana, profitabilitas untuk mengukur efektifitas manajemen berdasarkan hasil pengembalian yang di peroleh dari penjualan dan investasi dengan modal kerja yang memadai, selain itu di dukung pula dengan peningkatan volume hal ini terbukti dari penjualan (hasil penjualan) maka profitabilitas UD Nila Kencana pun akan meningkat karena disadari betul betapa pentingnya arti keuntungan bagi masa depan UD Nila Kencana. Berdasarkan uraian latar belakang yang telah dipaparkan di atas, UD Nila Kencana harus bisa menyeimbangkan antara keuntungan yang didapatkan dengan biaya yang dikeluarkan secara efektif dan efisien agar nantinya dapat meningkatkan profit dari tahun ke tahun.

\section{LANDASAN TEORI}

\section{Modal kerja}

Sutrisno (2009), "Modal kerja merupakan salah satu unsur aktiva yang sangat penting dalam perusahaan karena tanpa modal kerja perusahaan tidak dapat memenuhi kebutuhan untuk menjalankan aktivitasnya" Penggunaan modal kerja akan menyebabkan perubahan bentuk maupun penurunan jumlah aktiva lancar yang dimiliki perusahaan, namun tidak selalu penggunaan aktiva lancar diikuti dengan perubahan dan penurunan jumlah modal kerja yang dimiliki perusahaan. Misalnya penggunaan aktiva lancar untuk (a)Jangka panjang, melunasi hutang lancar, maka penggunaan aktiva lancar ini tidak mengakibatkan penurunan jumlah modal kerja karena penurunan aktiva lancar tersebut diikuti atau diimbangi dengan penurunan hutang lancar dalam jumlah yang sama. Berikut merupakan penggunaan modal kerja yang akan mengurangi modal kerja, Agnes Sawir (2005), (b) Berkurangnya modal sendiri karena kerugian, maupun pengambilan privasi oleh pemilik perusahaan. (c) Adanya penambahan atau pembelian aktiva tetap Sementara Munawir (2010), penggunaan-penggunaan aktiva. Sumber Modal Kerja Djarwanto (2001) mengemukakan bahwa pada umumnya modal kerja suatu perusahaan berasal dari berbagai sumber, yaitu: (a)Hasil Operasi Perusahaan (b) Keuntungan dari Penjualan Surat-surat Berharga (Investasi Jangka Pendek) (c) Penjualan Aktiva Tetap, Investasi Jangka Panjang dan Aktiva Tidak Lancar (d) Penjualan Saham atau Obligasi (e) Dana Pinjaman dari Bank dan Pinjaman Jangka Pendek Lainnya (f) Kredit dan Supplier.

\section{Profitabilitas}

Profitabilitas (Harahap: 2009) adalah Rasio rentabilitas atau disebut juga profitabilitas menggambarkan kemampuan perusahaan mendapatkan laba melalui semua kemampuan, dan sumber yang ada seperti kegiatan penjualan, kas, modal, jumlah karyawan, jumlah cabang, dan sebangainya. Rasio yang menggambarkan kemampuan perusahaan menghasilkan laba disebut juga Operating Ratio.

\section{METODE}

\section{Populasi dan sampel}

Populasi ialah wilayah generasi yang terdiri dari subjek dan objek yang memiliki kualitas dan karakter tertentu yang ditetapkan oleh penelitian guna untuk dipelajari lalu kemudian dibuat kesimpulannya (Sugiono, 2016:80). Dalam penelitian ini, jenis 
penelitian yang yang dipilih adalah dengan penelitian deskriptif dengan pendekatan kuantitatif atau fieldresearch yaitu suatu metode penelitian yang bersifat induktif, objektif dan ilmiah dimana data yang di peroleh berupa angka-angka yang di nilai, dan dianalisis.

\section{HASIL DAN PEMBAHASAN}

\section{Analisis SWOT matrix}

Strategi SO yang cocok bagi perusahaan yaitu: (1) Memperluas daerah pemasaran mengingat masih besarnya potensi customer baru di luar daerah sekarang; (2) Menggunakan teknologi untuk meningkatkan produktivitas agar lebih efisien; (3) Perluasan target pasar pada masyarakat yang peduli kesehatan untuk menghindari persaingan yang terlalu ketat dan perang harga. Sedangkan pada sisi WO strategi yang cocok bagi perusahaan ialah: (1) Memaksimalkan fungsi marketing untuk dapat memaksimalkan peluang pasar karena marketing perusahaan sangat kurang dimana aktivitas yang rutin dilakukan hanya pengiriman; (2) Meningkatkan kapasitas produksi, karena sebelum memaksimalkan penjualan tentunya harus dapat memproduksi lebih untuk dapat menyediakan lebih banyak produk untuk dijual; (3) Memperbaiki struktur modal yang terlalu konvensional untuk dapat meningkatkan kapasitas modal dan profitabilitas. Strategi ST yang cocok bagi perusahaan yaitu : (1) Memiliki sumber pasokan bahan baku sendiri untuk meminimalkan ancaman besar berupa ketidakstabilan harga bahan baku; (2) Melakukan aktivitas lindung nilai bila pengambilan bahan baku dari impor untuk mencegah kerugian kurs. Strategi WT yang cocok dijalankan perusahaan yaitu memperbaiki pengelolaan agar makin banyak informasi tersedia untuk pengambilan keputusan, hal ini penting karena tingginya persaingan menuntut pengambilan keputusan yang cepat dan tepat.

\section{Neraca}

Neraca adalah laporan keuangan yang memperlihatkan harta, utang, dan modal perusahaan pada waktu tertentu secara seimbang. Neraca dapat dikatakan seimbang apabila harta perusahaan jumlahnya sama dengan utang yang ditambah modal (Harta = Utang + Modal). Neraca digunakan untuk tingkat pengembalian dan mengevaluasi struktur modal perusahaan. Selain itu, neraca juga dapat digunakan untuk menilai likuiditas, solvabilitas, dan fleksibilitas keuangan perusahaan. Berikut adalah neraca secara sederhana.

\section{Laporan laba/rugi}

Laporan laba/rugi adalah adalah laporan yang mengukur kinerja operasional perusahaan selama periode tertentu. Tujuan dibuatnya laporan ini adalah untuk mengetahui hasil kinerja operasi perusahaan, untung atau rugi, yang disusun dalam laporan laba/ rugi adalah penjualan bersih dan biaya yang dikeluarkan selama periode tertentu. Perusahaan dikatakan untung apabila total pendapatan lebih besar dari total biaya dan dikatakan rugi apabila total pendapatan lebih kecil dari total biaya. Kegunaan laporan laba/rugi adalah untuk mengevaluasi kinerja masa lalu perusahaan, memberikan dasar untuk memprediksi kinerja masa depan, dan membantu menilai resiko ketidak pastian arus kas.

\section{Laporan perubahaan modal}


Laporan Perubahan modal kerja menunjukkan adanya perubahan elemen modal kerja yaitu aktiva lancar dan kewajiban lancar setelah digunakan untuk membiayai suatu kegiatan usaha perusahaan dalam satu periode. Sehingga dengan laporan perubahan modal kerja dapat menggambarkan kenaikan atau penurunan modal kerja pada periode tertentu

Berdasarkan Tabel 1. menunjukkan kenaikan modal kerja sebesar Rp 40.424,677, kenaikan pada modal kerja ini disebabkan adanya kenaikan yang cukup signifikan pada aktiva lancar. Sedangkan pada hutang lancar juga mengalami kenaikan pada hutang dagang.

Tabel 1. Laporan perubahan modal kerja UD nila kencana 2017-2018

\begin{tabular}{lrrr}
\hline Keterangan & $\mathbf{2 0 1 7}$ & $\mathbf{2 0 1 8}$ & Perubahan \\
\hline Aktiva & & & \\
Aktiva lancar & & & \\
Kas & $88,648,215$ & $76,554,844(12,093,371)$ \\
Piutang usaha & $35,225,050$ & $31,408,325$ & $(3,816,725)$ \\
Persediaan & $29,599,750$ & $57,145,065$ & $27,545,315$ \\
Perlengkapan & 918,905 & $1,210,752$ & 291,847 \\
Aktiva lancar lainnya & 281,050 & 404,139 & 123,089 \\
Total aktiva lancar & $\mathbf{1 5 4 , 6 7 2 , 9 7 0}$ & $\mathbf{1 6 6 , 7 2 3 , 1 2 5}$ & $\mathbf{1 2 , 0 5 0 , 1 5 5}$ \\
Pasiva & & & \\
Hutang lancar & & & \\
Hutang dagang & $27,278,933$ & $25,612,276$ & $(1,666,657)$ \\
Jumlah hutang & & & \\
Lancar & & $\mathbf{2 5 , 6 1 2 , 2 7 6}$ & \\
Jumlah modal kerja & $127,394,037$ & $141,110,849$ & \\
Kenaikan modal kerja & & & $\mathbf{1 3 , 7 1 6 , 8 1 2}$ \\
\hline
\end{tabular}

Sumber: Darta diolah, 2018

Selanjutnya Tabel 1 menunjukkan kenaikan modal kerja sebesar Rp 13.716.812, kenaikan pada modal kerja ini disebabkan adanya kenaikan yang cukup signifikan pada aktiva lancar. Sedangkan pada hutang lancar mengalami penurunan pada hutang dagang.

\section{Analisis pengelolaan modal kerja}

Data yang digunakan dalam analisis pengelolaan unsur-unsur modal kerja berupa neraca, laporan laba-rugi selama tiga periode, yaitu tahun 2016, 2017, 2018. Kedua laporan keuangan tersebut dapat digunakan untuk menilai beberapa aspek tertentu dari operasi perusahaan. Analisis pengelolaan unsur-unsur modal kerja meliputi:

\section{Pengelolaan kas}

Jumlah kas yang ada dalam perusahaan tidak boleh berlebihan, karena akan menyebabkan dana tidak produktif. Sebaliknya, jumlah kas terlalu kecil akan mengganggu kontinuitas perusahaan, sehingga besar-kecilnya kas harus disesuaikan dengan kebutuhan.

$$
\text { Pengelolaan Kas }=\frac{\text { Kas }}{\text { Penjualan }} \times 100 \%
$$

Tabel 2. Pengelolaan kas UD. nila kencana 


\begin{tabular}{|c|c|c|c|c|}
\hline Keterangan & 2016 & 2017 & \multicolumn{2}{|c|}{2018} \\
\hline$\overline{\text { Kas }}$ & & $41,650,352$ & $88,648,215$ & $76,554,844$ \\
\hline Penjualan & & $151,214,700$ & $236,385,900$ & $197,935,829$ \\
\hline
\end{tabular}

Sumber: Darta diolah, 2018

\section{Pengelolaan piutang}

Peningkatan volume penjualan yang tidak seimbang dengan peningkatan piutang usaha akan menyebabkan menumpuknya modal kerja yang tertanam dalam piutang usaha.

Receivable Turnover $=\frac{\text { Penjualan Kredit }}{\text { Piutang Rata-rata }} \times 1$ Kali

Tabel 3. Receivable turnover UD.nila kencana

\begin{tabular}{lrrr}
\hline Keterangan & $\mathbf{2 0 1 6}$ & $\mathbf{2 0 1 7}$ & $\mathbf{2 0 1 8}$ \\
\hline Penjualan kredit & $151,214,700$ & $236,385,900$ & $197,935,829$ \\
Piutang & $23,709,175$ & $35,225,050$ & $31,408,325$ \\
Piutang rata-rata & $23,709,175$ & $29,467,113$ & $33,316,688$ \\
\hline Receivable turnover & 6.38 kali & 8.02 kali & 5.94 kali \\
\hline
\end{tabular}

Sumber: Darta diolah, 2018

$$
\text { Aerage Collection Periode }=\frac{\text { Rata }- \text { rata Plutang }}{\text { Penjualan Kredit }} \times 360 \text { Hari }
$$

Tabel 3. Average collection periode ud. nila kencana

\begin{tabular}{|c|c|c|c|}
\hline Keterangan & 2016 & 2017 & 2018 \\
\hline Piutang rata-rata & $23,709,175$ & $29,467,113$ & $33,316,688$ \\
\hline Penjualan kredit & $151,214,700$ & $236,385,900$ & $197,935,829$ \\
\hline Average collection periode & 56 hari & 45 hari & ari \\
\hline
\end{tabular}

Sumber: Darta diolah, 2018

\section{Pengelolaan persediaan}

Persediaan pada umumnya yang jumlahnya cukup besar dalam suatu perusahaan. Persediaan elemen modal kerja yang paling likuid sehingga diperlukan pengelolaan yang baik.

$$
\text { Inventory turnover }=\frac{\mathrm{BPP}}{\text { Rata }- \text { rata persediaan }} \times 1 \mathrm{Kali}
$$

Tabel 4. Inventori turnover UD. nila kencana 


\begin{tabular}{lrrr}
\hline Keterangan & $\mathbf{2 0 1 6}$ & $\mathbf{2 0 1 7}$ & $\mathbf{2 0 1 8}$ \\
\hline Beban pokok penjualan & $129,409,000$ & $169,973,600$ & $171,673,655$ \\
Persediaan & $42,172,978$ & $29,599,750$ & $57,145,065$ \\
Rata-rata persediaan & $42,172,978$ & $35,886,364$ & $43,372,408$ \\
\hline Inventory Turnover & $3.07 \mathrm{kali}$ & $4.74 \mathrm{kali}$ & $3.96 \mathrm{kali}$ \\
\hline
\end{tabular}

Sumber: Darta diolah, 2018

$$
\text { Rage age of inventory }=\frac{\text { Rata }- \text { rata persediaan }}{\mathrm{BPP}} \times 360 \mathrm{Hari}
$$

Tabel 5. Average age of inventory ud. nila kencana

\begin{tabular}{lrrr}
\hline Keterangan & $\mathbf{2 0 1 2}$ & $\mathbf{2 0 1 3}$ & $\mathbf{2 0 1 4}$ \\
\hline Rata-rata persediaan & $42,172,978$ & $35,886,364$ & $43,372,408$ \\
Beban pokok penjualan & $129,409,000$ & $169,973,600$ & $171,673,655$ \\
\hline Average age of inventory & 117 hari & 76 hari & 91 hari
\end{tabular}

Sumber: Darta diolah, 2018

\section{Pengelolaan hutang lancar}

Besarnya hutang lancar harus disesuaikan dengan kebutuhan pendanaan perusahaan. Jumlah hutang lancar yang terlalu besar akan menyebabkan uang tunai yang ada dalam perusahaan semakin besar sehingga hal ini sangat tidak menguntungkan karena adanya dana yang tertanam pada kas dan setara kas yang tidak produktif.

Account payable turnover $=\frac{\text { Pembelian }}{\text { Rata-rata hutang dagang }} \times 1 \mathrm{Kali}$

Tabel 6. Account payabele turnover UD. nila kencana

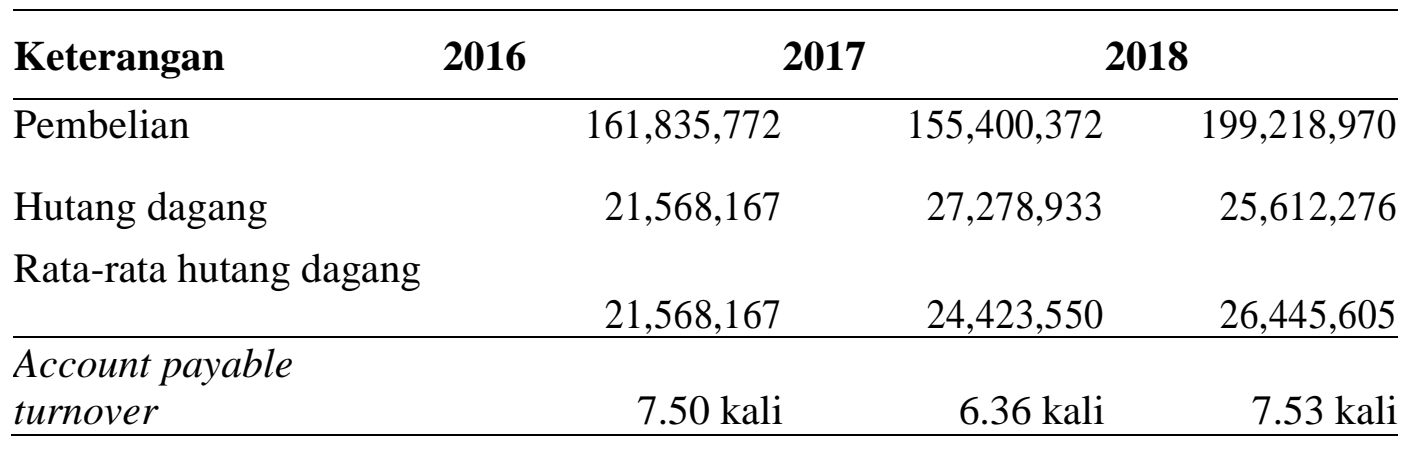

Sumber: Darta diolah, 2018

\section{Pengelolaan modal kerja bersih}

Net working capital merupakan selisih dari aktiva lancar dengan hutang lancar. Net working capital yang tinggi menunjukkan tingkat likuiditas yang tinggi pada perusahaan, 
dan sebaliknya jika net working capital dari tahun ke tahun menurun maka bisa dikatakan bahwa tingkat likuiditas menurun.

Net working capital $=$ aktiva lancar - hutang lancar

Tabel 7. Net working capital UD. nila kencana

\begin{tabular}{lrrr}
\hline Keterangan & $\mathbf{2 0 1 6}$ & $\mathbf{2 0 1 7}$ & $\mathbf{2 0 1 8}$ \\
\hline Aktiva lancar & $108,537,527$ & $154,672,970$ & $166,723,125$ \\
Hutang lancar & $21,568,167$ & $27,278,933$ & $25,612,276$ \\
\hline Net working capital & $86,969,360$ & $127,394,037$ & $141,110,849$ \\
\hline
\end{tabular}

Sumber: Darta diolah, 2018

\section{Rasio profitabilitas}

Rasio profitabilitas merupakan rasio yang menggambarkan kemampuan perusahaan dalam mendapatkan laba melalui semua kemampuan dan sumber yang ada seperti kegiatan penjualan, kas, modal, jumlah karyawan, jumlah cabang dan sebagainya.

\section{Gross profit margin}

Gross profit margin $=\frac{\text { Penjualan bersih }-\mathrm{HPP}}{\text { Penjualan Bersih }} \times 100 \%$

Tabel 8. Gross profit margin

\begin{tabular}{lrrr}
\hline Keterangan & $\mathbf{2 0 1 6}$ & $\mathbf{2 0 1 7}$ & $\mathbf{2 0 1 8}$ \\
\hline Laba kotor & $21,409,700$ & $66,712,300$ & $26,262,174$ \\
Penjualan nersih & $151,214,700$ & $236,385,900$ & $197,935,829$ \\
\hline Gross profit margin & $14.16 \%$ & $28.22 \%$ & $13.27 \%$ \\
\hline
\end{tabular}

Sumber: Darta diolah, 2018

\section{Operating profit margin}

Operating profit margin $=\frac{\text { Laba Operasi }}{\text { Penjualan }}$

Tabel 9. Operating profit margin

\begin{tabular}{lrrr}
\hline Keterangan & $\mathbf{2 0 1 6}$ & $\mathbf{2 0 1 7}$ & $\mathbf{2 0 1 8}$ \\
\hline Laba operasi & $22,644,000$ & $67,657,700$ & $27,003,286$ \\
Penjualan & $151,214,700$ & $236,385,900$ & $197,935,829$ \\
\hline Operating profit margin & $14.97 \%$ & $28.62 \%$ & $13.64 \%$ \\
\hline
\end{tabular}

Sumber: Darta diolah, 2018 


\section{Net profit margin}

$$
\text { Net pofit margin }=\frac{\text { Laba bersih setelah pajak }}{\text { Penjualan bersih }} \times 100 \%
$$

Tabel 10. Net profit margin

\begin{tabular}{lrrr}
\hline Keterangan & $\mathbf{2 0 1 6}$ & $\mathbf{2 0 1 7}$ & $\mathbf{2 0 1 8}$ \\
\hline Laba bersih sesudah & & & \\
Pajak & $5,758,000$ & $53,843,000$ & $11,596,073$ \\
Penjualan bersih & $151,214,700$ & $236,385,900$ & $197,935,829$ \\
\hline Net Profit Margin & $3.81 \%$ & $22.78 \%$ & $5.86 \%$ \\
\hline
\end{tabular}

\section{Return on invesment (ROI)}

$R O I=\frac{\text { Laba Bersih Setelah Pajak }}{\text { Total aktiva }} \times 100 \%$

Tabel 11. Return of invesment

\begin{tabular}{lrrr}
\hline Keterangan & $\mathbf{2 0 1 6}$ & $\mathbf{2 0 1 7}$ & $\mathbf{2 0 1 8}$ \\
\hline Laba bersih sesudah & & & \\
Pajak & $5,758,000$ & $53,843,000$ & $11,596,073$ \\
Total aktiva & $108,537,527$ & $154,672,970$ & $166,723,125$ \\
\hline
\end{tabular}

Return on investment

Sumber: Darta diolah, 2018

$5.31 \% \quad 34.81 \% \quad 6.96 \%$

\section{Return on equity (ROE)}

$$
R O E=\frac{\text { Laba Bersih Setelah Pajak }}{\text { Modal Sendiri }} \times 100 \%
$$

Tabel 12. ROE UD. nila kencana

\begin{tabular}{lrrr}
\hline Keterangan & $\mathbf{2 0 1 6}$ & $\mathbf{2 0 1 7}$ & $\mathbf{2 0 1 8}$ \\
\hline Laba bersih sesudah pajak & & & \\
& $5,758,000$ & $53,843,000$ & $11,596,073$ \\
\hline Retun on equity & $4.68 \%$ & $30.43 \%$ & $6.15 \%$ \\
\hline Modal sendiri & $123,110,047$ & $176,953,047$ & $188,549,120$
\end{tabular}

Sumber: Darta diolah, 2018

\section{Keterkaitan antara modal kerja dengan profitabilitas}

Pada setiap perusahaan modal kerja mempunyai keterkaitan dengan profitabilitas, karena dengan modal kerja perusahaan dapat memenuhi kewajiban jangka pendeknya, dimana modal kerja digunakan untuk menjalankan operasi perusahaan setiap harinya. Sedangkan profitabilitas untuk menunjukkan kemampuan perusahaan dalam memenuhi kewajiban yang harus dipenuhi. 
Di sini modal kerja pada UD. Nila Kencana pada tahun 2016-2018 sangat baik, karena jumlah Net Working Capital mengalami peningkatan setiap tahunnya. Dari sini dapat dikatakan bahwa manajemen modal kerja pada perusahaan sudah sangat baik dalam mengelola modal kerja perusahaan. Pada tingkat profitabilitas UD. Nila Kencana menunjukkan adanya tingkat hubungan dengan modal kerja. Pada tahun 2016-2016 dapat dikatakan tingkat profitabilitas pada Gross profit margin, Operating profit margin, Net profit margin, Return of investment, Return on equity berfluktuatif dan pada modal kerja sendiri juga mengalami fluktuatif tahun 2016-2017. Disini dapat dilihat pada waktu modal kerja periode 2016-2017 mengalami peningkatan sedangkan pada profitabilitas juga mengalami peningkatan, selanjutnya pada periode 2017-2018 modal kerja mengalami peningkatan dan pada profitabilitas mengalami penurunan.

Di dalam hasil penelitian yang penulis teliti, hasilnya bertolak belakang dengan teori yang ada, hasil penelitian menunjukkan tingkat Net working capital yang meningkat pada tahun 2017-2018 tidak diimbangi dengan peningkatan laba perusahaan pada tahun 2017-2018. pengelolaan modal kerja (Syamsuddin, 2011) merupakan kegiatan yang berkenaan dengan manajemen current account perusahaan yaitu aktiva lancar dan hutang lancar.Pengelolaan-pengelolaan aktiva lancar dan hutang lancar secara efektif dengan menggunakan kebijakan yang tepat akan memberikan hasil berupa laba yang ditargetkan. pengelolaan modal kerja pada tahun 2016-2017 sudah efektif dengan pembuktian meningkatnya modal kerja yang diimbangi peningkatan laba perusahaan. Sedangkan pada tahun 2017-2018 keefektifan peningkatan modal kerja tidak diimbangi dengan peningkatan laba perusahaan. Hal ini disebabkan adanya kenaikan harga bahan pokok produksi yang menunjukkan naiknya tingkat pembelian pada tahun 2018 , dan berimbas pada meningkatnya beban pokok penjualan, disisi lain pada tahun 2017-2018 perusahaan memprediksi jika pada tahun 2019 akan terjadi peningkatan produksi, oleh karena itu perusahaan merekrut karyawan tetap, sehingga menyebabkan terjadinya penambahan karyawan tetap yang menyebabkan naiknya beban operasi yang berimbas menjadi turunnya laba bersih.

\section{KESIMPULAN DAN SARAN}

\section{Kesimpulan}

Hasil Analisa menunjukkan bahwa pengelolaan modal kerja yang efisien meningkatkan modal kerja di tahun 2016-2017, yang diimbangi dengan meningkatnya laba perusahaan pada tahun 2016-2017. Hasil Analisa menunjukkan bahwa pengelolaan modal kerja yang efisien meningkatkan modal kerja di tahun 2017-2018, akan tetapi tidak diimbangi dengan meningkatnya laba perusahaan di tahun 2017-2018. Hal ini disebabkan adanya kenaikan harga bahan pokok produksi yang menunjukkan naiknya tingkat pembelian pada tahun 2018, dan berimbas pada meningkatnya beban pokok penjualan, disisi lain pada tahun 2017-2018 perusahaan memprediksi jika pada tahun 2019 akan terjadi peningkatan produksi, oleh karena itu perusahaan merekrut karyawan tetap, sehingga menyebabkan terjadinya penambahan karyawan tetap yang menyebabkan naiknya beban operasi yang berimbas menjadi turunnya laba bersih.

\section{Saran}

Sesuai dengan kesimpulan tersebut, penulis ingin memberikan saran yang mungkin dapat bermanfaat bagi perusahaan atau sebagai bahan pertimbangan dalam masalah yang 
berhubungan dengan materi yang penulis bahas. Adapun saran yang ingin penulis sampaikan adalah sebagai berikut: ('1) Bagi perusahaan Penulis menyarankan, seharusnya pemilik usaha menaikkan harga jual ketika harga pembelian bahan baku mengalami kenaikkan, agar laba yang diinginkan tetap tercapai, atau dengan alternatif meminimalkan jumlah pembelian dengan mencari supplier kedelai lain dengan harga yang rendah tetapi tidak mengurangi kualitas kedelai. Peneliti menyarankan penambahan pegawai seharusnya disistem secara outsourcing agar ketika penjualan meningkat perusahaan tidak mengalami kesulitan dalam hal memasok produksi, dan ketika permintaan mengalami penurunan, perusahaan tidak mengalami tingginya tingkat beban operasi yang disebabkan oleh karyawan yang tidak dibutuhkan. (2) Bagi penelitian selanjutnya, diharapkan penelitian ini bisa menjadi sarana untuk menerapkan serta membandingkan antara ilmu yang diperoleh dari bangku perkuliahan dengan keadaan yang sebenarnya secara langsung pada obyek penelitian, sehingga dapat mengetahui penerapan teori dalam perusahaan serta menambah informasi atau pengetahuan dan pengalaman dalam dunia kerja.

\section{DAFTAR PUSTAKA}

Agoes, S \& Estralita, T. (2010). Akuntansi perpajakan. Edisi satu revisi: Jakarta.

Akbar, Rusdi. (2004). Akuntansi Pengantar. UPP STIM YKPN: Jogjakarta

Amirullah, Imam Hardjanto. (2005). Pengantar Bisnis, Graha Ilmu: Yogyakarta

Ardi, Muhammad. (2005). Analisis faktor-faktor yang mempengaruhi kinerja keuangan PT. Berdikari United Livestock. Skripsi. Fakultas Ekonomi Universitas Hasanudin. Makassar.

Arikunto, S. (2010). Prosedur Penelitian. Rineka Cipta: Jakarta:

Budiman, E, Sifrid, P, \& Steven, T. (2014. Analisis perlakuan akuntansi aktiva tetap pada pt hasjrat multifinance manado.Jurnal EMBA. 2(1), 411-420.

Fatimah, (2008). Pengaruh utang jangka panjang terhadap rentabilitas pada pt excelcomindo Pratama Tbk. (Jurnal on-line). Internet.http://library. gunadarma.ac.id/repository/view/7992/pengaruh-utang-jangka-panjang-

terhadap-rentabilitas pada-pt-excelcomindo Jakarta: -ratama Tbk. Diakses pada tanggal 3 Maret 2013.

Firdaus, A. (2010). Ikhtisar lengkap pengantar akuntansi, Edisi ke Tiga, Jakarta.

Ghozali, Imam. (2011). Aplikasi analisis multivariate dengan program SPSS. Badan Universitas Diponogoro: Semarang.

Martini, A. (2014). Analisis faktor-faktor yang berpengaruh terhadap kinerja keuangan PT. Berdikari United Livestock. Ak.Men Jurnal Ilmiah, 11(4). 462-471, https://doi.org/10.37476/akmen.v11i4.246

Hartono.(2008). Akuntansi keuangan menengah. Edisi Kesatu. Cetakan Kesatu. Badan Fakultas Ekonomi: Yogyakarta

Hery. (2011). Akuntansi aktiva, hutang dan modal, Edisi ke Sebelas, Gava Media: Jakarta

Hilmi, M. 2010. Analisis penggunaan hutang terhadap profitabilitas pada perusahaan telekomunikasi yang Go Public di BEI Periode 2004-2009. Skripsi. Fakultas Ekonomi Universitas Islam Negeri Malang.

Ikatan Akuntan Indonesia, (2007). Standar Akuntansi Keuangan.Salemba Empat: Jakarta

Irawan, Andy Ramadhan. (2014). Analisis pengelolaan modal kerja untuk meningkatkan likuiditas dan profitabilitas. Universitas Brawijaya Malang. (online), 
tersedia: http://administrasibisnis.studentjournal.ub.ac.id. diunduh 29 Agustus 2019.

Irham. (2011). Analisis laporan keuangan. Elfabeta: Hal 198

Ismiati, Nike. (2012). Pengaruh perputaran modal kerja terhadap profitabilitas perusahaan. Artikel Ilmiah Hasil Penelitian Mahasiswa 2013.

Jember. Jumingan. (2011). Analisis laporan keuangan. PT.Bumi Askara: Jakarta

Kalia,Nazia Safitri, (2013). Pengaruh penggunaan hutang terhadap profitabilitas pada Pt Semen Gresik Tbk. Jurnal Ilmu dan Riset Manajemen. 1(1)

Kasmir. (2007). Kewirausahaan. PT Raja Grafindo: Jakarta

Kasmir. (2010). Analisis laporan keuangan. PT Raja Garfindo Persada: Jakarta

Mardiasmo. (2012. Akuntansi sektor publik. Edisi ke 3: BPFE. Yogyakarta

Mardiyatmo. (2008). Kewirausahaan untuk SMK kelas XI. Yudistira: Jakarta

Martono dan Agus Harjito. (2005). Manajemen keuangan.cetakan kelima, Ekonsia: Yogyakarta

Munawir, S. (2010). Analisa laporan keuangan. Liberty: Yogyakarta: 